\title{
THE OUTSTANDING PERSONALITY OF THE TWENTIETH CENTURY: NAZIB ZHIGANOV (ON HIS 110TH ANNIVERSARY)
}

\author{
Gulnaz Nailevna Akbarova, \\ Kazan Federal University, \\ 18 Kremlyovskaya Str., Kazan, 420008, Russian Federation, \\ g.akbarova@list.ru.
}

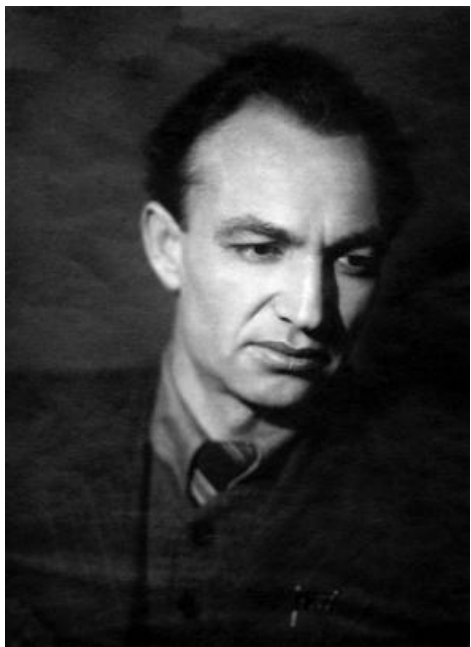

Zhiganov Nazib Gayazovich (January 15，1911-June 2，1988) was a composer, music and public figure, teacher, Honored Art Worker of the TASSR (1939), RSFSR (1940), the first chairman of the Union of Composers of Tatarstan, the Secretary of the Union of Composers of the USSR (from 1962) and the RSFSR (from 1957), People's Artist of the USSR (1957), professor (1953), laureate of State Prizes, holder of numerous orders and medals, Hero of Socialist Labor.

In 1938, he graduated from the Moscow Conservatory, G. Litinsky class of composition. In 1939-1977, he was the Chairman of the Board of the Union of the TASSR Composers' Organizing Committee.

In 1941-1943, Nazib Zhiganov was the artistic director of the Tatar Opera and Ballet Theater.

1945-1988, he was the rector of the Kazan Conservatory.

Zhiganov was also: a member of the Committee for the Republican Prize named after G. Tukay (from 1958); a member of the committees for awarding the Lenin and State Prizes in the field of literature and
Жиһанов Нәжип Гаяз улы (1911 елның 15 гыйнвары -1988 елның 2 июне) - композитор, музыка һәм жәмәгать эшлеклесе, педагог, ТАССРның атказанган сәнгать эшлеклесе (1939), РСФСР (1940), Татарстан Композиторлар берлегенең беренче рәисе, СССР Композиторлар берлеге секретаре (1962) hәм РСФСРның (1957), СССРның халык артисты (1957), профессор (1953), Дәүләт премияләре лауреаты, күпсанлы орден һәм медальләр иясе, Социалистик Хезмәт Герое.

1938 елда Г. Литинский исемендәге композиция классы буенча Мәскәү консерваториясен тәмамлый.

1939-1977 елларда ТАССР Композиторлар берлегенең оештыру комитеты, идарә рәисе. 1941-1943 елларда Татар опера һәм балет театрының сәнгать житәкчесе. 1945-1988 елларда Казан консерваториясе ректоры.

Н. Жиһанов шулай ук Г. Тукай исемендәге республика премиясе буенча комитет әгъзасы булып тора (1958 елдан);
Жиганов Назиб Гаязович (15 января 1911 г. - 2 июня 1988 г.) композитор, музыкальный и общественный деятель, педагог, заслуженный деятель искусств ТАССР (1939), РСФСР (1940), первый председатель Союза композиторов Татарстана, секретарь Союза композиторов СССР (с 1962) и РСФСР (с 1957), народный артист СССР (1957), професcop (1953), лауреат Государственных премий, обладатель многочисленных орденов и медалей, Герой Социалистического Труда.

В 1938 г. окончил Московскую консерваторию по классу композиции у Г. Литинского.

В 1939-1977 гг. председатель организационного комитета, правления Союза композиторов TACCP.

В 1941-1943 гг. художественный руководитель Татарского театра оперы и балета.

В 1945-1988 гг. ректор Казанской консерватории.

Жиганов также являлся членом Комитета по республиканской премии им. Г. Тукая (с 1958), членом комитетов по присужде- 
art under the Council of Ministers of the USSR (from 1961); a Deputy of the Supreme Soviets of the RSFSR (1951-1959), the TASSR (19631967 and 1971-1988) and the USSR (1966-1970).

The composer's creative heritage consists of 17 symphonies, 8 operas, 3 ballets, program symphonic works, chamber instrumental works, vocal and choral compositions. әдәбият һәм сәнгать өлкәсендә СССР Министрлар Советы каршындагы Ленин һәм Дәүләт премияләре буенча комитет әгъзасы (1961 елдан); РСФСР Югары Советлары депутаты (1951-1959), 1963-1967 hәм 19711988 елларда ТАССР Югары Советы һәм 1966-1970 елларда СССР Югары Советы депутаты.

Композиторның ижади мирасы: 17 симфония, 8 опера, 3 балет, программ симфоник әсәрләре, камера-инструменталь әсәрләр, вокаль һәм хор әсәрләре. нию Ленинской и Государственной премии в области литературы и искусства при СМ СССР (с 1961), депутатом Верховных Советов РСФСР (1951-1959), ТАCCP (1963-1967 и 1971-1988), СССР (1966-1970).

Творческое наследие композитора составляют 17 симфоний, 8 опер, 3 балета, программные симфонические произведения, камерно-инструментальные произведения, вокальные и хоровые сочинения.

\begin{abstract}
"The temple of music, created by the artistic energy of Nazib Zhiganov, is not only the Kazan Conservatory, now bearing his name, but also in fact, the entire modern musical culture of Tatarstan ".
\end{abstract}

R. Abdullin

The year of 2021 marks the $110^{\text {th }}$ anniversary of the greatest Tatar composer Nazib Zhiganov (1911-1988) whose personality played a huge role in the formation and development of Tatar professional music.

Nazib Zhiganov was born into a working class family in Uralsk on January 15, 1911. Having lost his parents early, he became a pupil of an orphanage. From a young age, Nazib Zhiganov eagerly participated in the activities of pioneer groups, helped in the preparation of musical numbers for various events. Music occupied a special place in the life of the young man. He mastered piano playing on his own, learned to play by ear and improvise. In 1928, Nazib Zhiganov entered the Kazan Musical College in cello (R. L. Polyakova) and piano (M. A. Pyatnitskaya). Two years later, he was sent to the Moscow Regional Music College where he studied at the composer department in the class of G. I. Litinsky.

Within the walls of this Music College, Zhiganov's first works were created - piano and vocal works, arrangements of Tatar folk songs. The String Quartet became his diploma work. After the concert performance of this work, Zhiganov was immediately enrolled in the third year of the Moscow Conservatory.

In subsequent years, the name of Nazib Zhiganov was associated with many significant dates in the history of Tatar culture: the first symphony of the composer opened the Tatar State Philharmonic Society (1937), his opera "Kachkyn"
(The Fugitive) (the composer's diploma work at the conservatory) opened the Tatar State Opera and Ballet Theater ( 1939), the opera "Altynchuch" (The Golden-haired) grandly opened a new theater building (1956), which in the same year was named after the Hero of the Soviet Union Tatar poet Musa Jalil. In 1941-1943, Zhiganov was the artistic director of this theater. The name of Nazib Zhiganov is also closely associated with the activities of the Union of Composers of Tatarstan, Zhiganov was its first chairman, as well as the secretary of the Union of Composers of the RSFSR (from 1957) and the USSR (from 1962). From 1958 , the composer was a member of the Committee for the Republican Prize named after G. Tukay, as well as a member of the committees for awarding the Lenin and State Prizes in Literature and Art under the Council of Ministers of the USSR (from 1961).

Nazib Zhiganov was one of those who initiated the creation of the Kazan State Conservatory (1945) and the Secondary Special Music School (1960). From the moment the conservatory was opened until the end of his days, he was its permanent rector whose efforts were devoted to the development of professional musical education in Tatarstan. In 1945, the piano, orchestral, vocal, conductor-choral, theoretical and composer faculties were established at the conservatory. To prepare national musicians, Zhiganov invited the best teachers from all over the country, including the conductor Nathan Rakhlin. Thus, the Tatar composer school was formed and Kazan performing schools were created (for example, the Kazan school of choral conducting). Also, student ensembles were created: a symphony orchestra (directed by J. G. Sadrizhiganov), a choir chapel (its director and conductor was S. A. Kazachkov) (1947), an orchestra of folk instruments (1961), a brass band 
(its first director and conductor was Sh. G. Nizamutdinov) (1970), the Chamber Orchestra of the Conservatory (its director and conductor was V. A. Afanasyev) (1979) and chamber ensembles. In 1972, thanks to Zhiganov, an organ appeared in the republic, and an organ class was opened at the conservatory (1979). Students not only from the Volga region, but also from other parts of the country studied at the conservatory. All this gave a great impetus to the development of the musical culture in many national republics. In 2001, the Kazan State Conservatory was named after Nazib Gayazovich Zhiganov.

While studying at the Moscow Conservatory, Zhiganov closely communicated with many cultural figures from Tatarstan, including composers J. Faizi, A. Klyucharev, M. Muzafarov, F. Yarullin and others. His acquaintance with the poet Musa Jalil grew into a great friendship [Dulat-Aleev, p. 242]. Subsequently, it influenced the composer's creative musical trend. Nazib Zhiganov devoted a lot of time and effort to the development of the national theater, to the creation of musical and stage genres in Tatar music and the implementation of national traditions in professional music in general. He created such musical and theatrical masterpieces as: the operas "Kachkyn" (The Fugitive) (1938), "Irek" (Freedom) (1939), "Altynchuch" (The Golden-haired) (1941), "Ildar" (1942; "A Road to Victory" in the 2nd edition, 1954), "Tuluk" (Tyulyak) (1944; "Tyulyak and Su-Slu" in the 2nd edition, 1967), "Shagyir" (The Poet) (1947), "Namus" (Honor) (1950), "Jalil" (1956); the ballets "Fatykh" (1943), "Zehrə" (Zuhra) (1944; the 2nd edition, 1969), "Nzheri” (1969).

In many of his operas, social issues are raised (the themes of uprisings, the struggle against oppression and the enslavement of man, intertwined with the fate of people in love). The opera "Kachkyn" depicts the events of the Pugachev uprising through the tragedy of two lovers; in "Altynchuch", the theme of the struggle of the Tatar people with the Mongol conquerors is shown; "Irek" is devoted to the October Revolution; the plots of the operas "Ildar", "Namus" and "Jalil" are connected with the Great Patriotic War.

Deep psychological insight, the national element, the wide scope of the crowd scenes and the heartfelt theme of lyrical scenes make it possible to define the personality of the composer as an outstanding thinker who had a subtle sense of this world.

Many decades have passed since Zhiganov's first operas were created, but the themes, raised by the composer in his works, remain relevant in the 21 st century. Today, there is a tendency to restore Zhiganov's musical and theatrical opuses on the big stage, an interest in opera is awakening.

In 2011, the Opera Studio of the Kazan Conservatory staged N. Zhiganov's opera "Altynchuch" in the Kazan Kremlin (as part of the First International Opera Festival "Kazan Autumn"). Nazib Zhiganov completed work on his opera in February 1941. This performance about the struggle of the Bulgars against the Mongol horde was staged ten days before the start of the Great Patriotic War (June 12, 1941) and received a special response from the audience. 70 years later, the image of Altynchuch was revived on the big stage and was again warmly received by the public. The walls and square of the Kazan Kremlin, inside which the musical and stage performances took place, in combination with the music of Zhiganov, added a special flavor to the production, creating a sense of belonging to the history of our people.

In 2017 and 2019, Zhiganov's opera "Tyulyak and Su-Slu", which crowned the creative work of the composer, was performed in Kazan and Moscow. The plot of the opera "Tyulyak" is based on a collection of various fairy tales and legends of the Volga-Ural Turks, telling about fortitude, strength, courage, true love and self-sacrifice for the sake of lofty goals, as well as the complex internal contradictions of the main characters. The profound philosophy, history and national traditions, inherent in the opera, were "regained" from the archival "oblivion" and raised to a new level by the efforts of the Opera Studio at the Kazan State Conservatory. For several years - the first production was staged in 2017, the last in 2019 - the prominent figures of Kazan, who made up a professional team of like-minded people, worked on the stage implementation of this opera.

Zhiganov wrote the opera during the last years of the Great Patriotic War (in 1944-1945) when the image of the people's defender had a special meaning. The modern reading of the opera is a look of our contemporaries into the past to experience those events through the prism of their own understanding and perception. The 2017 performance was dedicated to the composer Nazib Zhiganov and the outstanding conductor Fuat Mansurov, who participated in the performance of all of the composer's operas. Later, within the framework of the $14^{\text {th }}$ International Theater Festival of Turkic Peoples "Nauruz", the production acquired new live scenery - Lake Kaban and a huge 
wall on the embankment near the theater named after G. Kamal, which added a certain archaism and special flavor to the performance. Moreover, the opera could be seen by a much larger number of listeners than in a concert hall or on a theatre stage. A great achievement was the staging of this performance in Moscow, within the framework of the Fourth Festival of Russian Musical Theaters "See Music". The national epic was shown to the sophisticated public of the capital and was a great success.

This opera has a special musical language one can hear the intonations of Tatar folk songs, its leitmotifs are close to the folk themes; at the same time, the solo parts have intonation moves unusual for Tatar music, which are not easy to perform, there is a frequent change of meter and a complex harmonic language in some places ... Many researchers draw an analogy between Zhiganov's opera "Tyulyak" and the fairy-tale operas by the composer Rimsky-Korsakov, noting new ways of using nationally characteristic harmonic means: various uses of pentachords; quarto-quint parallelisms as a special paint depicting the traditional "sound ideal" (the term coined by I. Zemtsovsky) of the Volga-Ural Turks. This technique was immediately further developed in the work of Tatar composers.

As Artemy Zarifov notes in his dissertation on Zhiganov's opera works, "Tyulyak and Su-Slu" is based on the recitative-declamatory type of thematism, the structure of which goes back to the Wagnerian-type musical drama, characterized by a high degree of thematic concentration and motivational interaction [Zarifov, p. 23]. Zhiganov expanded the stylistic origins of melody from folklore similarity to generalized melody, while preserving the national intonation of the thematism.

The storyline of the opera requires a lot of acting, maturity of mind, and, simultaneously, youthful passion and insane energy. The theme of defending the homeland is framed by the images of the main characters and their personal experiences. The image of Tyulyak, for example, is permeated with deep psychologism [Motigullina, p. 161], the main character often finds himself in a situation of choice, on which not only his life hinges, but also the lives of those around him. The performance raises questions of moral guidelines, rare human qualities that are relevant at all times.

Zhiganov's operas are full of plot lines, the images of a mystical and real nature, small scenes with the participation of 2-3 characters and massive choral scenes. These are full-fledged classical operas, containing certain performing difficulties, with their own philosophy and amplitude.

Zhiganov is a composer of opera and symphonic thinking. The author laid the foundations for his operas in symphonic genres, chamber instrumental compositions, romances and songs [Aksiuk, p. 23]. The orchestral fabric of his operas is permeated with thematism, a variety of timbres and colors, the composer's tendency to symphonize the opera is also expressed in his desire for the cross-cutting development.

For the Tatar people, resuming the stage life of his most complex and very important national operas, such as "Altynchuch", "Tyulyak and Suslu", means to give them hope for the preservation and transmission of the best examples of national culture and history to the younger generation, hope for the preservation of the native language and manifestation of respect for their traditions and their own roots.

Zhiganov's opera oeuvre is truly multifaceted; however, the most extensive field of the composer's activity is his symphonic works. The creation of program compositions for a symphony orchestra, based on the national melos, triggered the formation of Tatar symphony. The composer created a whole layer of works for a symphony orchestra: 17 symphonies, a symphonic poem "Kyrlay" (1946), a suite on Tatar themes for a symphony orchestra (1949), an overture for a symphony orchestra "Nafise" (1952), "Symphony novellas" (1963), "Symphonic Songs" (1965).

Each of the composer's 17 symphonies is unique. "Like operas and ballets, each of the symphonic scores recreates a rich artistic and imaginative world, imbued with a vivid feeling of national poetry, song folklore, pictures of nature and folk life, close to the worldview of modern man" [Kompozitory ..., p. 67]. For the creation of the Second Symphony "Sabantuy" the composer was awarded the State Prize of the USSR (1970).

Symphonism and the scale of the composer's thinking penetrate into vocal and choral music. For example, the cantata "My Republic" (1960, lyrics by N. Arslanov) is permeated with the melodic breadth, rich choral and piano texture, the textured and dynamic development to the end of this work.

It is difficult to overestimate the contribution of Zhiganov to the formation and development of Tatar musical culture. His creative, pedagogical, organizational and social activities promoted the emergence of a whole galaxy of talented people, national professionals who received world fame and recognition. Thanks to the composer's efforts, 
Tatarstan today can be proud of outstanding composers, musicologists, performers and teachers who graduated from the Kazan State Conservatory and the secondary special music school at the conservatory.

Zhiganov's work as a composer characterizes him as a far-sighted person of large-scale thinking, a keeper of traditions, emphasizing his importance in the history of the Tatar people. His music is a fusion of national melos and the experience of world musical culture. Zhiganov laid down the traditions of national classical music, becoming an innovator, educator and engine of progress for his era. He raised Tatar culture to the world level.

Zhiganov's personality has been widely recognized. Competitions, festivals and conferences are held in honor of the composer, his oeuvre is discussed in articles and dissertations. In 2011, on the composer's centenary, the Ministry of Culture of the Republic of Tatarstan named the Kazan State Conservatory after N. G. Zhiganov; the International Competition of Composers named after $\mathrm{N}$. G. Zhiganov was held, as well as the conference "Nazib Zhiganov and Contemporary Musical Culture".
On May 20, 1996, a minor planet was named in honor of Nazib Gayazovich Zhiganov, it was registered in the international catalog under No. 5930 and received the name "ZHIGANOV".

\section{References}

Aksiuk, S. (1980). Opera N. Zhiganova "Dzhalil"" [N. Zhiganov's Opera "Jalil"]. Aksiuk S. O muzyke: Stat'i i retsenzii. Pp. 73-76. Moscow, Sov. Kompozitor. (In Russian)

Dulat-Aleev, V. R. (2018). Istoricheskaya tema $v$ tatarskoy opere [Historical Theme in the Tatar Opera]. Muzyka. Iskusstvo, nauka, praktika. No. 4 (24), pp. 8389. (In Russian)

Kompozitory i muzykovedy Sovetskogo Tatarstana (1986) [Composers and Musicologists of Soviet Tatarstan]. Pp. 65-71. Kazan'. (In Russian)

Motigullina, A., Zamaliyeva, L., Khabutdinova, M. (2017). Ideino-khudozhestvennoe svoeobrazie libretto N. Isanbeta k opere "Tiuliak" [N. Isanbet's Libretto of the Opera "Tulak": Ideological and Artistic Originality]. Filologiia i kul'tura. Philology and culture. No. 4(50), pp.160-166. (In Russian)

Zarifov, A. Sh. (2005). Opernoe tvorchestvo Naziba Zhiganova $v$ aspekte sredstv vyrazheniia natsional'noi spetsifiki : avtoref. dis. ... kand. iskusstvovedeniia [Opera Work of Nazib Zhiganov in Terms of Expressing National Specificity: Ph. D. Thesis Abstract]. Moscow, 28 p. (In Russian)

\title{
ВЫДАЮЩАЯСЯ ЛИЧНОСТЬ ХХ ВЕКА: НАЗИБ ЖИГАНОВ (К 110-ЛЕТИЮ СО ДНЯ РОЖДЕНИЯ)
}

\author{
Гульназ Наилевна Акбарова, \\ Казанский федеральный университет, \\ Россия, 420008, г. Казань, ул. Кремлевская, д. 18, \\ g.akbarova@list.ru.
}

\begin{abstract}
Храм музыки, созданный творческой энергией Назиба Жиганова, это не только Казанская консерватория, ныне носящая его имя, а, по сути, вся современная музыкальная культура Татарстана. Р. К. Абдуллин
\end{abstract}

В 2021 году исполняется 110 лет со дня рождения величайшего татарского композитора Назиба Гаязовича Жиганова (1911-1988), который сыграл огромную роль в становлении и развитии татарской профессиональной музыки.

Назиб Жиганов родился в Уральске 15 января 1911 года в рабочей семье, однако, рано потеряв родителей, он стал воспитанником детского дома. С юных лет Назиб Гаязович актив- но участвовал в деятельности пионерских отрядов, помогал в подготовке музыкальных номеров для различных мероприятий. Музыка занимала особое место в жизни юноши. Он самостоятельно освоил игру на фортепиано, научился подбирать по слуху, импровизировать. В 1928 году Назиб Жиганов поступает в Казанский музыкальный техникум по классу виолончели (Р. Л. Полякова) и фортепиано (М. А. Пятницкой). Через два года его направляют в Московский областной музыкальный техникум, где он учится на композиторском отделении в классе Г. И. Литинского.

В стенах техникума рождаются первые сочинения Жиганова: фортепианные и вокальные произведения, обработки татарских народных 
песен. Дипломной работой стал Струнный квартет. После концертного исполнения этого сочинения было принято решение принять Жиганова сразу на третий курс Московской консерватории.

Имя Назиба Жиганова связано со многими знаменательными датами в истории татарской культуры: Первой симфонией композитора открылась Татарская государственная филармония (1937), оперой «Качкын» («Беглец») (дипломная работа композитора в консерватории) состоялось открытие Татарского государственного театра оперы и балета (1939), оперой «Алтынчәч» («Золотоволосая») торжественно открылось новое здание театра (1956), которому в этом же году было присвоено имя Героя Советского Союза, татарского поэта Мусы Джалиля. В 1941-1943 годах Жиганов являлся художественным руководителем данного театра. Имя Назиба Жиганова также тесно связано с деятельностью Союза композиторов Татарстана, Жиганов являлся первым его председателем, а также секретарем Союза композиторов РСФСР (с 1957) и СССР (с 1962). С 1958 года композитор был членом Комитета по республиканской премии им. Г. Тукая, а также членом комитетов по присуждению Ленинской и Государственной премии в области литературы и искусства при СМ СССР (с 1961).

Назиб Жиганов стал одним из инициаторов создания Казанской государственной консерватории (1945) и средней специальной музыкальной школы (1960). С момента открытия консерватории и до конца своих дней он являлся бессменным ректором, отдававшим все силы становлению профессионального музыкального образования в Татарстане. В 1945 году в консерватории были образованы фортепианный, оркестровый, вокальный, дирижерско-хоровой, теоретико-композиторский факультеты. Для обучения национальных кадров Жиганов приглашал лучших педагогов со всей страны, в том числе дирижера Натана Рахлина. Таким образом, формировалась татарская композиторская школа, создавались казанские исполнительские школы (к примеру, казанская школа хорового дирижирования). Кроме того, создавались студенческие коллективы: симфонический оркестр (руководитель Дж. Г. Садрижиганов), хоровая капелла (руководитель и дирижер С. А. Казачков) (1947), оркестр народных инструментов (1961), духовой оркестр (первый руководитель и дирижер Ш. Г. Низамутдинов) (1970), Камерный оркестр консерватории (руководитель и дирижер - В. А. Афанасьев) (1979), камерные ансамбли. В 1972 году, благодаря Жиганову, в республике появился орган, а в консерватории открылся органный класс (1979). В консерватории обучались студенты не только Поволжья, но и других уголков страны. Все это дало большой толчок для развития музыкальной культуры многих национальных республик. В 2001 году Казанской государственной консерватории было присвоено имя Назиба Гаязовича Жиганова.

Еще в годы учебы в московской консерватории Жиганов тесно общался со многими деятелями культуры из Татарстана, в том числе с композиторами Дж. Файзи, А. Ключаревым, М. Музафаровым, Ф. Яруллиным и другими. Знакомство с поэтом Мусой Джалилем переросло в большую дружбу [Дулат-Алеев, с. 242], что впоследствии отразилось на творческой деятельности композитора. Назиб Гаязович много сил и времени уделял развитию национального театра, созданию музыкальносценических жанров в татарской музыке и преломлению национальных традиций в профессиональной музыке в целом. Он создал такие музыкально-театральные шедевры, как оперы «Качкын» («Беглец») (1938), «Ирек» («Свобода») (1939), «Алтынчәч» («Золотоволосая») (1941), «Ильдар» (1942; во 2-й редакции «Дорога победы», 1954), «Түләк» («Тюляк») (1944; во 2-й редакции «Тюляк и Су-Слу», 1967), «Шагыйрь» («Поэт») (1947), «Намус» («Честь») (1950), «Джалиль» (1956); балеты «Фатых» (1943), «Зөһрә» («Зухра») (1944; 2-я редакция 1969), «Нжери» (1969).

Многие его оперные произведения посвящены социальным темам (темы восстаний, борьбы против гнета, порабощения человека, переплетающиеся с судьбой влюбленных людей). В опере «Качкын» через трагедию двух влюбленных отражаются события пугачевского восстания, в «Алтынчәч» освещается тема борьбы татарского народа с монгольскими завоевателями, в «Ирек» - Октябрьская революция, сюжеты опер «Ильдар», «Намус» и «Джалиль» связаны с Великой Отечественной войной.

Глубокий психологизм, национальное начало, широкий размах массовых сцен и проникновенный тематизм лирических сцен позволяют выделить личность композитора как выдающегося мыслителя, тонко чувствующего этот мир. 
С момента написания первых опер Жиганова прошло много десятилетий, однако темы, к которым обращался композитор в своих сочинениях, продолжают оставаться актуальными и в XXI веке. В настоящее время пробуждается интерес к музыкально-театральным опусам Жиганова.

В 2011 году Оперной студией Казанской консерватории была осуществлена постановка оперы Н. Жиганова «Алтынчәч» в Казанском Кремле (в рамках Первого Международного оперного фестиваля «Казанская осень»). Назиб Жиганов завершил работу над оперой в феврале 1941 года. Спектакль о борьбе булгар с монгольской ордой был поставлен за десять дней до начала Великой Отечественной войны (12 июня 1941 г.) и вызвал положительный отклик у слушателей. Спустя 70 лет образ Алтынчеч возродился на большой сцене и снова был горячо воспринят публикой. Стены и площадь Казанского Кремля, внутри которого происходило музыкально-сценическое действо, в сочетании с музыкой Жиганова способствовали созданию особой атмосферы, когда слушатели имели возможность погрузиться в историю своего народа.

В 2017 и 2019 гг. в Казани и Москве прозвучала опера «Тюляк и Су-Слу» Жиганова, ставшая итогом оперного творчества композитора. Сюжет оперы Тюляк основывается на собрании различных сказок и легенд волгоуральских тюрков, повествующих о стойкости, силе, отваге, истинной любви и самопожертвовании ради высоких целей, о сложных внутренних противоречиях главных героев. Глубокая философия, история и национальные традиции, заложенные в опере, были «вскрыты» из архивного «забвения» и подняты на новый уровень силами Оперной студии Казанской государственной консерватории. На протяжении нескольких лет - первая постановка была осуществлена в 2017 году, последняя в 2019 году над сценической реализацией данной оперы работали видные деятели Казани, составляющие профессиональную команду единомышленников.

Жиганов писал оперу в годы окончания Великой Отечественной войны (в 1944-1945 годы), образ защитника народа тогда имел особый смысл. Современное прочтение оперы это взгляд наших современников в прошлое и переживание событий сквозь призму собственного понимания и восприятия. Спектакль 2017 года был посвящен композитору Назибу Жига- нову и выдающемуся дирижеру Фуату Мансурову, участвовавшему в исполнении всех опер композитора. Позже, в рамках XIV международного театрального фестиваля тюркских народов «Науруз», постановка обрела новые живые декорации - озеро Кабан и огромную стену на набережной возле театра им. Г. Камала, что придало представлению некую архаичность и особый колорит. Кроме того, в таком месте спектакль могли увидеть большое количество слушателей, нежели в концертном зале или оперной сцене. Большим достижением явилась постановка данного спектакля в Москве в рамках Четвертого фестиваля музыкальных театров России «Видеть музыку». Национальный эпос был продемонстрирован искушенной публике столицы и имел большой успех.

Музыкальный язык оперы особый - в нем проглядываются интонации татарской народной песни, близкие к народному тематизму лейтмотивы, в то же время появляются непростые для исполнения нетрадиционные для татарской музыки интонационные ходы в солирующих партиях, присутствует частая смена метра, а также местами сложный гармонический язык. Многие исследователи проводят аналогию оперы Жиганова «Тюляк» со сказочными операми композитора РимскогоКорсакова, отмечая новые пути использования национально-характерных гармонических средств: разнообразное применение пентаккордов, кварто-квинтовые параллелизмы как особая краска, изображающая традиционный «звуковой идеал» (термин И. Земцовского) волгоуральских тюрков. Этот прием сразу же получил дальнейшее развитие в творчестве татарских композиторов.

Как отмечает Артемий Зарифов в диссертации об оперном творчестве Жиганова, «Тюляк и Су-Слу» основана на речитативнодекламационном типе тематизма, структура которого восходит к музыкальной драме вагнеровского типа, отличающейся высокой степенью тематической концентрации, мотивного взаимодействия [Зарифов, с. 23]. Жиганов расширял стилевые истоки мелодики от схожести с фольклором до мелодики обобщенного типа, при этом сохраняя национальную интонационность тематизма.

Сюжетная линия оперы требует большой актерской игры, зрелости ума, в то же время юношеской страсти и безумной энергии. Тема защиты родины обрамляется образами главных персонажей и их личностными переживаниями. 
Образ Тюляка, к примеру, пронизан глубоким психологизмом [Мотигуллина, с. 161], главный герой часто оказывается в ситуации выбора, от которого зависит не только его жизнь, но и жизнь тех, кто его окружает. Спектакль поднимает вопросы нравственных ориентиров, редкостных человеческих качеств, являющихся актуальными во все времена.

Оперы Жиганова насыщены сюжетными линиями, образами мистического и реального характера, малыми картинами, с участием 2-3 героев, и массовыми хоровыми сценами. Это полноценные классические оперы, содержащие определенные исполнительские трудности, со своей философией и большим масштабом.

Жиганов - композитор оперно-симфонического мышления. Основы для своих опер автор закладывал в симфонических жанрах, камерноинструментальных сочинениях, в романсах и песнях [Аксюк, с. 23]. Оркестровая ткань его опер пронизана тематизмом, разнообразием тембров и красок, тенденция композитора к симфонизации оперы также выразилась в стремлении к сквозному развитию.

Возобновление сценической жизни сложнейших и очень важных для татарского народа национальных опер, таких как «Алтынчәч», «Тюляк и Суслу» Н. Жиганова, дает надежду на сохранение лучших образцов национальной культуры, истории, на сбережение родного языка, проявление уважения к традициям и собственным корням.

Оперное творчество Жиганова поистине многогранно, однако наиболее обширной сферой деятельности композитора является симфоническое творчество. Создание программных сочинений для симфонического оркестра на основе национального мелоса послужило началом формирования татарского симфонизма. Композитором написан целый пласт сочинений для симфонического оркестра: 17 симфоний, симфоническая поэма «Кырлай» (1946), Сюита на татарские темы для симфонического оркестра (1949), увертюра для симфонического оркестра «Нафисе» (1952), «Симфонические новеллы» (1963), «Симфонические песни» (1965).

Каждая из 17 симфоний композитора уникальна. «Подобно операм и балетам, в каждой из симфонических партитур воссоздается богатый художественно-образный мир, проникнутый живым ощущением национальной поэзии, песенного фольклора, картин природы и народной жизни, близких мироощущению совре- менного человека» [Композиторы..., с. 67]. За создание Второй симфонии «Сабантуй» композитор был удостоен Государственной премии СССР (1970).

Симфонизм, масштабность мышления композитора проникает и в вокально-хоровую музыку. К примеру, кантата «Республика моя» (1960, слова Н. Арсланова) пронизана широтой мелодии, насыщенной хоровой и фортепианной фактурой, фактурным и динамическим развитием.

Трудно переоценить вклад Жиганова в формирование и развитие татарской музыкальной культуры. Творческая, педагогическая, организационная, общественная деятельность композитора способствовала возникновению целой плеяды талантливейших людей, национальных кадров, получивших мировую известность и признание. Благодаря стараниям композитора, Татарстан сегодня может гордиться выдающимися композиторами, музыковедами, исполнителями, педагогами, вышедшими из Казанской государственной консерватории и средней специальной музыкальной школы при консерватории.

Композиторское творчество Жиганова также характеризует его как дальновидного человека масштабного мышления, хранителя традиций, подчеркивая его значимость в истории татарского народа. В его музыке происходит сплав национального мелоса и опыта мировой музыкальной культуры. Жиганов заложил традиции национальной классической музыки, став для своей эпохи новатором, просветителем, двигателем прогресса. Он поднял татарскую культуру на мировой уровень.

Личность Жиганова получила широкое признание. В честь композитора проводятся конкурсы, фестивали, конференции, его творчество фигурирует в статьях и диссертациях ученых. В 2011 году к 100-летию композитора Министерством культуры Республики Татарстан и Казанской государственной консерваторией имени Н. Г. Жиганова был организован Международный конкурс композиторов имени Н. Г. Жиганова, а также конференция «Назиб Жиганов и музыкальная культура современности».

20 мая 1996 года в честь Назиба Гаязовича Жиганова названа малая планета, зарегистрированная в международном каталоге под №5930, которая получила имя «ZHIGANOV». 


\section{Литература}

Аксюк C. Опера Н. Жиганова «Джалиль» // С. Аксюк О музыке: Статьи и рецензии. М.: Сов. композитор, 1980. С. 73-76.

Дулат-Алеев В. Р. Историческая тема в татарской опере // Музыка. Искусство, наука, практика. 2018. № 4 (24). С. 83-89.

Зарифов Артемий Шамилевич. Оперное творчество Назиба Жиганова в аспекте средств выражения национальной специфики: автореф. дис. ... канд. искусствоведения. М., 200528 с.

Композиторы и музыковеды Советского Татарстана. Казань. 1986. С. 65-71.

Мотигуллина А., Замалиева Л., Хабутдинова М. Идейно-художественное своеобразие либретто $\mathrm{H}$. Исанбета к опере «Тюляк» // Филология и культура. Philology and culture. 2017. № 4 (50). C. 160-166. 